\title{
The Intelligent Management System Design and Development of Marketing History Archives
}

\author{
Jieyin Bai ${ }^{\mathrm{a}}$, Haifeng Lin ${ }^{\mathrm{b}}$, Erbo Shang ${ }^{\mathrm{c}}$, Lei Zhang ${ }^{\mathrm{d}}$ \\ Beijing Kedong Electric Power Control System co., LTD, Beijing, 100192, China \\ abaijieyin@sgepri.sgcc.com.cn, ${ }^{b}$ linhaifeng@sgepri.sgcc.com.cn, \\ cshangerbo@sgepri.sgcc.com.cn, dzhanglei7@ sgepri.sgcc.com.cn
}

Keywords: archives management, electronization, SOA.

\begin{abstract}
This paper describes the marketing history archive computerization management application oriented software system, from the architecture, function module, key technologies and so on, the characteristics of the system is expounded. The system includes file input; file hooking, archives check, file back print and other function module.
\end{abstract}

\section{Introduction}

After the intelligent file management system go online, paper and electronic files management resulted from marketing business process flow are implemented. But for generated history archives before marketing archives management system go online, it fails to realize electronic management of paper files [1] [2]. In order to effectively utilize marketing archives management system to manage history archive, ensure the information safety storage of marketing customer profile, and improve utilization and use value marketing archives, history archives that has been formed before marketing archives management system go online are sorted, electronized, after check complete finishing and warehousing, unified management are made. The electronic work realization of history realize recording, sorting and electronization of history archives, combined with online marketing archives management system, implement the generation, collection, filing and updating and whole process of electric power customer profiles are implemented, and which is closely related to marketing each business transaction process, timely collect, update, dynamically monitor, ensure the one to one correspondence of paper and electronic files and completeness, accuracy and real-time property of file content.

In this paper, according to the requirements of marketing archives management norms of state grid corporation, it provides a set of efficient, convenient electronic auxiliary solution for huge marketing amounts history archives, the electronic archives should be brought into the marketing archives information management scope. In the information management mode, ensure the integrity, security of whole life cycle of marketing electronic file, improve data sharing of business file, it is convenient for business personnel of each different position to read, raise the utilization ratio of archives; provide support for marketing business, it significantly improves the efficiency of the marketing business management.

\section{Demand Analysis}

The business requirements of history archives electronization include, [file input], [file hooking], [back print], etc. The overall flow chart is as follows figure 1: 


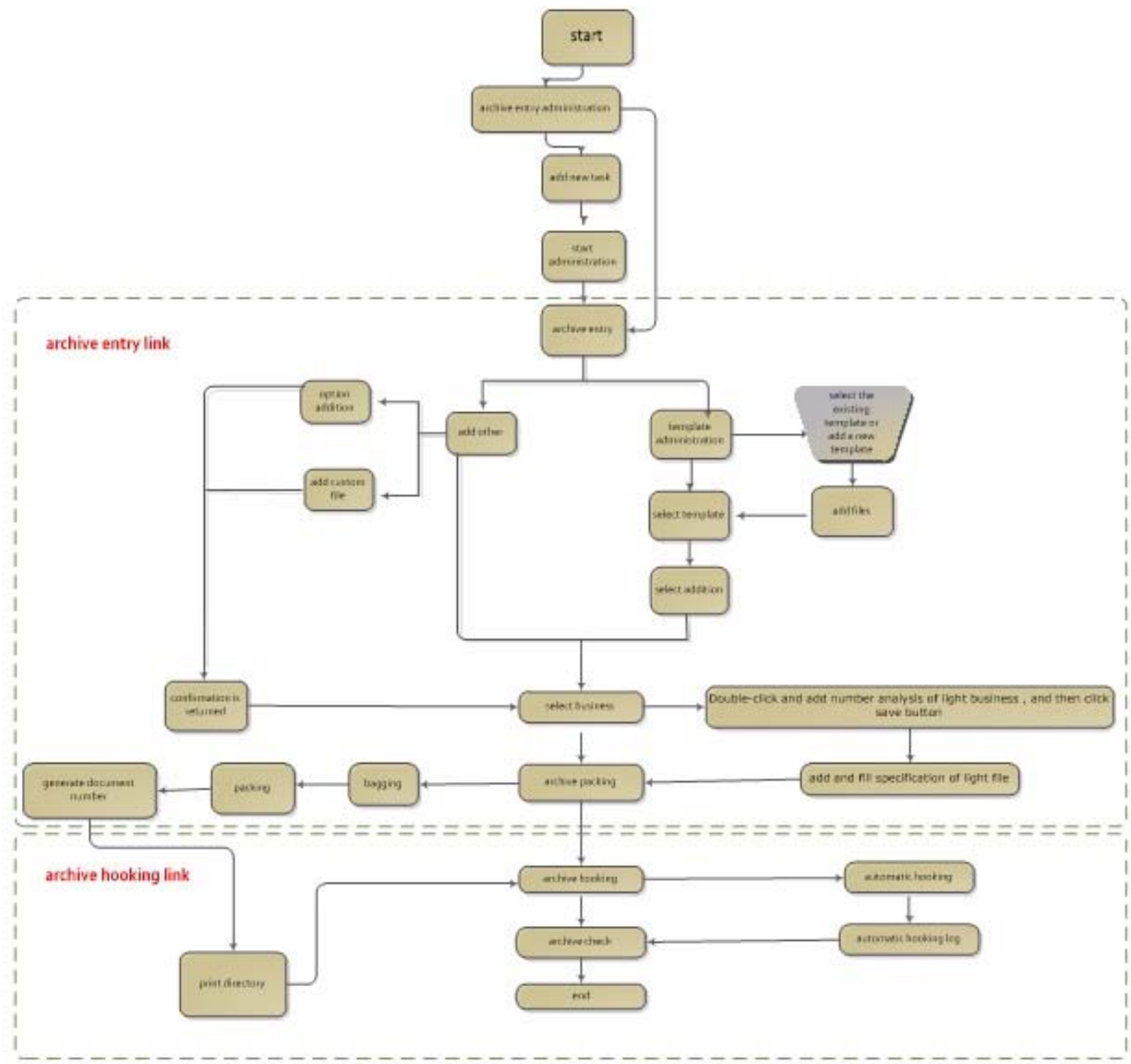

Fig. 1 the business requirements of history archives electronization

\section{Archive Record}

According to file management specification, this business determines collection rules of all kinds of data in the process of marketing business management, ensure the standardization, rationalization, staging of the data collection, including paper and electronic files formed in power supply utilization both in all kinds of electric activity, paper document delivery information is recorded at the same time.

Table 1. archive record

\begin{tabular}{|c|c|c|}
\hline name & description & character \\
\hline $\begin{array}{c}\text { initialization } \\
\text { template } \\
\text { management }\end{array}$ & $\begin{array}{c}\text { Add a new task, click "start arrangement", sorting status value is } \\
\text { "initialization" }\end{array}$ & $\begin{array}{c}\text { system } \\
\text { operators }\end{array}$ \\
\hline choose business & The file are selected business & $\begin{array}{c}\text { system } \\
\text { operators }\end{array}$ \\
\hline $\begin{array}{c}\text { template, etc. } \\
\text { archive } \\
\text { encapsulation }\end{array}$ & $\begin{array}{c}\text { The files are bagged (break up bag), boxed (dispersed box), and } \\
\text { generated file number, print directory, reading operation and so } \\
\text { on. }\end{array}$ & $\begin{array}{c}\text { system } \\
\text { operators }\end{array}$ \\
\hline
\end{tabular}


According to "the national grid company marketing customer archives electronic management norms", according to business requirements, the data should be timely done electronic documents encapsulation and business information electronization.

The business items mainly including initialization, template management, selecting business, file encapsulation.

\subsection{Archive Hooking}

This business describes personnel according to the archives hooking specifications, the file in accordance with the specified format automatically to hook up with user.

\subsection{Archive Check}

The business describes process that history archives management archives personnel check the archives after recording and hooking in the archive room and archive storehouse, it mainly checks, issued check conclusion, view check records for archive boxes, archive bag, entity archive inside the archive room and the corresponding electronic archives information ,etc.

\subsection{Back Printing}

This business describes after archive electronizing, paper files are stored in archive room, the print function of the back information of file box, through the query, print and other functions obtain the back information in file box and print. After back print by retrieving box barcode and RFID to confirm archive boxes that need print, display the related information of back in archive box such as the retention period, file number, and title for archive, barcode and so on.

Table 2. back printing

\begin{tabular}{|c|c|c|}
\hline name & description & character \\
\hline $\begin{array}{c}\text { archives } \\
\text { check query }\end{array}$ & $\begin{array}{c}\text { According to the archive box RFID, barcode of box, barcode of } \\
\text { bag to inquire archive information after hooking, inquire the } \\
\text { corresponding record to be checked. }\end{array}$ & $\begin{array}{c}\text { archive } \\
\text { management } \\
\text { personnel }\end{array}$ \\
\hline $\begin{array}{c}\text { Issue check } \\
\text { conclusion }\end{array}$ & $\begin{array}{c}\text { Aiming at checked records for check, and issue check "pass" or } \\
\text { "return" conclusion, check opinions can be put forward } \\
\text { confirm the } \\
\text { check }\end{array}$ & $\begin{array}{c}\text { After verifying, electronic archives information status changed } \\
\text { management } \\
\text { personnel }\end{array}$ \\
\hline
\end{tabular}

\subsection{Performance Requirements}

The system is able to cope with the biggest 100 registered users, the biggest online users 50 people, peak concurrent users 30 people application requirement, and meet the demand of the overall performance and stability of the system design.

Table 3. performance requirements

\begin{tabular}{|c|c|c|c|c|c|}
\hline \multirow{3}{*}{ function } & \multicolumn{5}{|c|}{ management capacity requirements of users with different levels } \\
\cline { 2 - 6 } & $\begin{array}{c}\text { below } 2 \\
\text { million }\end{array}$ & $\begin{array}{c}2 \text { million-5 } \\
\text { million }\end{array}$ & $\begin{array}{c}5 \text { million-10 } \\
\text { million }\end{array}$ & $\begin{array}{c}10 \text { million }-20 \\
\text { million }\end{array}$ & $\begin{array}{c}\text { above } \\
20 \text { million }\end{array}$ \\
\hline $\begin{array}{c}\text { scan and } \\
\text { upload }\end{array}$ & $\begin{array}{c}1000 \text { times } \\
\text { per hour }\end{array}$ & $\begin{array}{c}10000 \text { times } \\
\text { per hour }\end{array}$ & $\begin{array}{c}10000 \text { times per } \\
\text { hour }\end{array}$ & $\begin{array}{c}15000 \text { times } \\
\text { per hour }\end{array}$ & $\begin{array}{c}20000 \text { times } \\
\text { per hour }\end{array}$ \\
\hline $\begin{array}{c}\text { download and } \\
\text { check }\end{array}$ & $\begin{array}{c}1000 \text { times } \\
\text { per hour }\end{array}$ & $\begin{array}{c}20000 \text { times } \\
\text { per hour }\end{array}$ & $\begin{array}{c}20000 \text { times per } \\
\text { hour }\end{array}$ & $\begin{array}{c}30000 \text { times } \\
\text { per hour }\end{array}$ & $\begin{array}{c}50000 \text { times } \\
\text { per hour }\end{array}$ \\
\hline
\end{tabular}

\section{System Design}

\subsection{Overall Architecture}

History archives application make based data and collected electronic information generated by business in the historical archives platform before check, after check it is pushed to the unstructured data management platform and marketing archives management system. The fundamental data of organization and personnel information of the history archive management application need to copy from the marketing basic data platform. The overall architecture is as follows figure 2: 


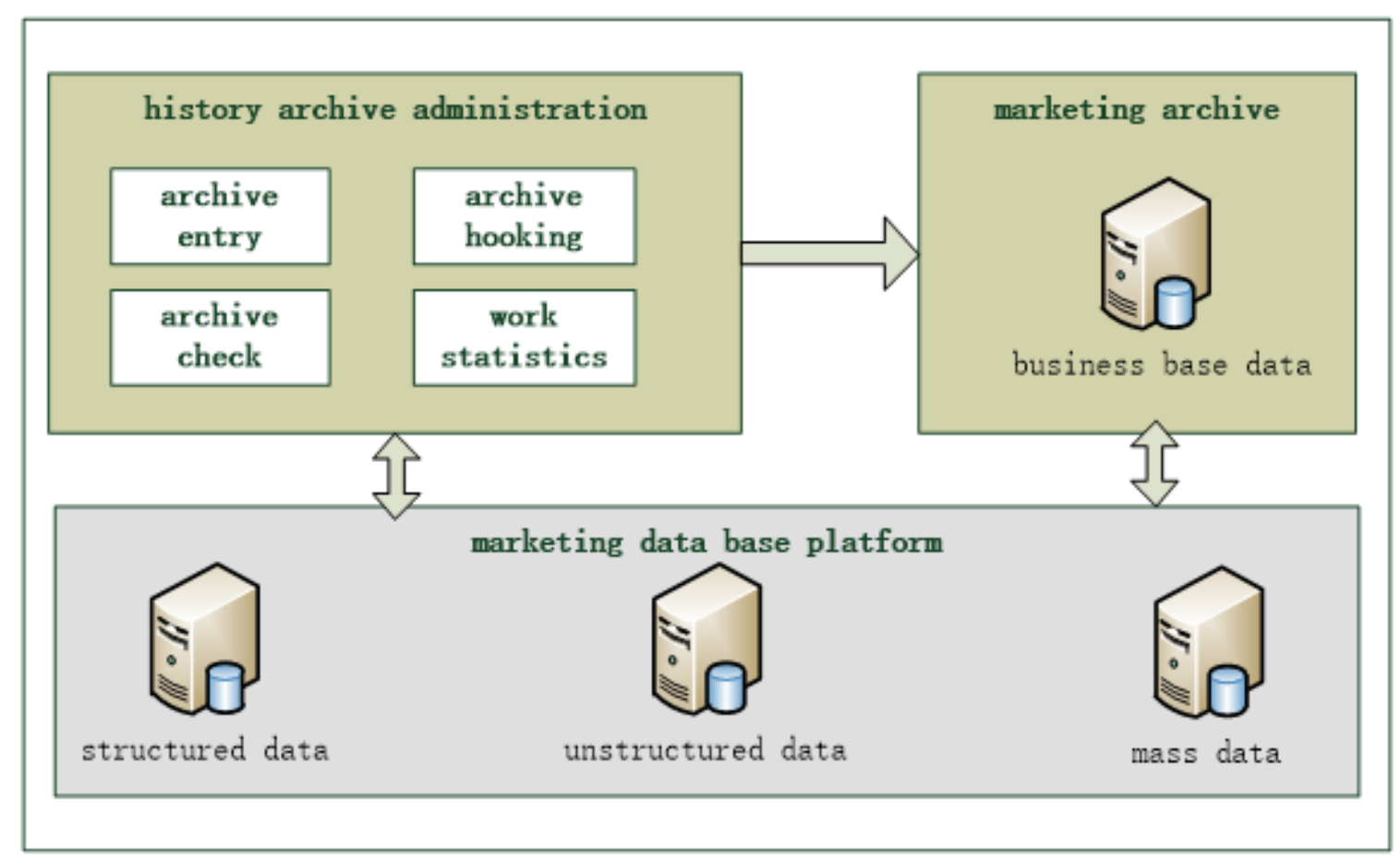

\subsection{Key Technology}

Fig. 2 the overall architecture

According to application architecture and the data structure design of the history archives system, combined with the current technical requirements and development trend of information technology, history archives application system by adopting the J2EE multilayer technology architecture combined with technology advancement and the maturity, in order to improve the flexibility scalability, security, and concurrent processing capacity of the system; state grid corporation application system unified development platform SG-UAP is utilized, based on the platform for upper application function development; At the same time, in the aspect of integrated design, the architecture strategy based on SOA is used, implement integration of enterprise internal business application system, enterprise external system [3] [4] [5] [6].

History archives system applications involving collection, storage, management, maintenance of large amounts of unstructured data, processing of unstructured electronic archives have three technical key points:

\subsubsection{Asynchronous concurrent storage technology}

Electronic files, audio and video files occupy larger bandwidth, under limiting the upload bandwidth condition, the transmission is for a long time, upload and continuing upload need to asynchronous processing, and concurrent upload of multiple terminals can be done queued task processing. The message queuing mechanisms and file buffer mechanism are used to handle asynchronous concurrency issues in file uploading.

\subsubsection{Intelligent text recognition technology}

Image and text recognition technology are that the high speed video shooting apparatus/scanner terminal equipment check the characters printed on paper, by testing the pattern of dark and bright to determine its shape, then using character recognition method to translated shape into computer language: that is scanning the text data, and then analyze and cope with the image file, the process of getting text and layout information. How to debug or the use auxiliary information to improve recognition accuracy, it is the key of this technology.

\subsection{Intelligent Search Technology}

Intelligent search engine is based on marketing business data resources and business classification, it by collection, organization, storage and use achieves the index library marketing archives and enrich search means, set up marketing comprehensive search engine. The manual and automatic timing from history archive application database and unstructured data management platform are 
realized to get the data in the database, set up document acquisition library and application link library, and form index documents, the search engines the document content are filtered, segmented, classified are done by search engine and form the enterprise's index file. Provide a set of uniform and reliable retrieval entrance, by fuzzy matching, full-text search, high-speed index and other technology to establish search engines, and provide accurate search positioning.

\subsection{Function Module Design}

Through analyzing all kinds of business for history archives application and combing application functions, extracting specific theme function and application function modules, depending on design methods and standards of the application architecture, design overall application function blueprint that meet history archives.

The application functions blueprint mainly includes archive input, archive hooking, archives check, statistical work four function modules:

Table 4. the application functions

\begin{tabular}{|c|c|c|}
\hline $\begin{array}{l}\text { function } \\
\text { noint name }\end{array}$ & function point content description & precondition \\
\hline $\begin{array}{l}\text { archive } \\
\text { input }\end{array}$ & $\begin{array}{l}\text { According to archive management specification This business determines } \\
\text { collection rules all kinds of data in process of marketing business } \\
\text { management, ensure the standardization rationalization, staging of the data } \\
\text { collection, specifically including paper documents and electronic files that } \\
\text { power supply and utilization both formed in all kinds of electric activity, } \\
\text { paper document delivery information are recorded at the same time. } \\
\text { According to the "national grid company marketing customer electronic } \\
\text { archives management norms", according to business requirements, the data } \\
\text { are timely done encapsulation of electronic documents and electronize } \\
\text { business information. The business items including (initialization), (template } \\
\text { management), (selection business), (archive encapsulation). }\end{array}$ & \\
\hline $\begin{array}{l}\text { archive } \\
\text { hooking }\end{array}$ & $\begin{array}{l}\text { Business personnel according to the archives hooking specification, data in } \\
\text { accordance with the specified format and user automatically hook, and } \\
\text { through the OCR recognition, the electronic document data are fetched to } \\
\text { save related database. Include (automatic hooking); (OCR recognition) } \\
\text { business sub items. }\end{array}$ & $\begin{array}{l}\text { archive record } \\
\text { completed }\end{array}$ \\
\hline $\begin{array}{l}\text { archive } \\
\text { check }\end{array}$ & $\begin{array}{l}\text { The business describes process that history archives management archives } \\
\text { personnel check the archives after recording and hooking in the archive room } \\
\text { and archive storehouse, it mainly checks, issued check conclusion, view } \\
\text { check records for archive boxes, archive bag, entity archive inside the archive } \\
\text { room and the corresponding electronic archives information, etc. } \\
\text { Includes (archives check), (view the check records) two business sub items. }\end{array}$ & $\begin{array}{l}\text { archive hooking } \\
\text { completed }\end{array}$ \\
\hline $\begin{array}{c}\text { work } \\
\text { statistics }\end{array}$ & $\begin{array}{l}\text { The business describes archive after the electronic process, in order to count } \\
\text { the actual workload of various implemented business people or working } \\
\text { group and information collected during the work process. Including the } \\
\text { (work statistics) sub item. }\end{array}$ & $\begin{array}{l}\text { archive record } \\
\text { completed } \\
\text { archive hooking } \\
\text { completed } \\
\text { archives check } \\
\text { completed }\end{array}$ \\
\hline
\end{tabular}

\section{Development Deployment}

\subsection{Technical Route}

The overall technical route of system development is as follows table 5: 
Table 5. the overall technical route of system development

\begin{tabular}{|c|c|c|c|}
\hline logic level & duty description & technical implementation & $\begin{array}{l}\text { communication } \\
\text { among the layers }\end{array}$ \\
\hline $\begin{array}{l}\text { presentation } \\
\text { layer }\end{array}$ & $\begin{array}{l}\text { 1, responsible for data display; } \\
\text { 2, responsible for receiving user } \\
\text { input data; }\end{array}$ & $\begin{array}{l}\text { 1, mainly use HTML, CSS, } \\
\text { JavaScript, SG-UAP MX } \\
\text { framework and other page } \\
\text { to display technology; } \\
\text { 2, statistical charts, } \\
\text { real-time monitoring uses } \\
\text { the FLEX display } \\
\text { technology. }\end{array}$ & $\begin{array}{l}\text { the layers use } \\
\text { HTTP }(\mathrm{s}) \text { protocol } \\
\text { to communicate }\end{array}$ \\
\hline $\begin{array}{l}\text { service } \\
\text { interaction } \\
\text { layer }\end{array}$ & $\begin{array}{l}\text { 1, call for requests of service } \\
\text { caller ; } \\
\text { 2, service following request } \\
\text { parameter call results. }\end{array}$ & $\begin{array}{c}\text { 1, use web service } \\
\text { technology; } \\
\text { 2, based on the SG-UAP } \\
\text { platform. }\end{array}$ & $\begin{array}{l}\text { Web service call, } \\
\text { the API call }\end{array}$ \\
\hline logic layer & $\begin{array}{l}\text { Provide the interface of business } \\
\text { logic, realize the business logic, } \\
\text { control affairs, provides a Web } \\
\text { service or call external Web } \\
\text { services provided by the } \\
\text { external system }\end{array}$ & $\begin{array}{c}\text { 1, use JavaBean, EJB to } \\
\text { develop; } \\
\text { 2, based on SG-UAP } \\
\text { platform development }\end{array}$ & API call \\
\hline $\begin{array}{l}\text { data access } \\
\text { layer }\end{array}$ & $\begin{array}{l}\text { the business logic and data } \\
\text { resources layer are effectively } \\
\text { isolated, standardize data } \\
\text { access and persist code, } \\
\text { provides a unified interface to } \\
\text { simplify the call externally. }\end{array}$ & $\begin{array}{l}\text { 1, JDBC, OR mapping } \\
\text { realize access to relational } \\
\text { database; } \\
\text { 2, use data in the SG-UAP } \\
\text { platform to access } \\
\text { components and } \\
\text { persistence components; }\end{array}$ & database API call \\
\hline $\begin{array}{c}\text { data resource } \\
\text { layer }\end{array}$ & $\begin{array}{c}\text { Comprised of relational } \\
\text { database, content library, file } \\
\text { system }\end{array}$ & $\begin{array}{l}\text { 1, use the Oracle database } \\
\text { to save relational data; } \\
2 \text {, use the content library, } \\
\text { the file system to save } \\
\text { unstructured electronic file } \\
\text { data. }\end{array}$ & \\
\hline
\end{tabular}

\subsection{System Integration Solutions}

History archives management applications and the integration of surrounding system include data integration, application integration, and interface integration three types, the overall integration relationship as shown in the below figure 3 .

1) The marketing basic data platform is done data integration, history archives application through the JDBC database access or WebService service invocation way to obtain basic data;

2) The marketing archives business application is made interface integration, the marketing archives business application integrates listing page.

3) The marketing archives business application through the WebService way to achieve application integration;

4) By calling the interface that the unstructured data management platform provides to implement archived unstructured data storage function;

5) Push controlled electronic files to marketing electronic file system; 
6) The unified access platform are made application integration, through the SG-UAP integrate unified access management platform to realize the identification, organization management, permission control, access control;

7) The workflow platform is done application integration, through the SG-UAP integrated business process to manage platform, support related applications function of business process;

8) IT operations management system (IMS) interface integration, by integrating the monitoring page of IMS to realize online monitoring of history archives application and operation condition;

9) The IT operations management system (IMS) is done application integration, invoke the Web Service data acquisition interface of IMS to upload system running status data into the IMS.

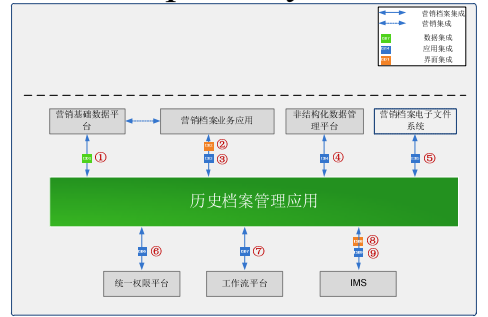

\subsection{Physical Deployment Scheme}

Fig. 3 he overall integration relationship

The physical architecture view of history archives application, it divided into production environment and test training environment two parts, the test training environment can be used for field test, simulation, and user training.

The constitutive situation of history archives application production environment is as follows:

1) Configure a disk array, which is used to provide a structured data storage of history archives management, short-term storage of undocumented electronic records;

2) Configure 2 fiber switches, constitute HA mode, and the disk array to constitute SAN network;

3) Configure 2 PC servers as the database server, constitute ORACLE 11.2.0.4+ASM + RAC pattern, provides the structured data management functions;

4) Configure multiple PC server, deploy WEBLOGIC $11 \mathrm{G}$, constitute the application server cluster, and undertake the Web application service.

5) Configure two load balancers to constitute HA model, which is used to provide application load balance access;

\section{Conclusions}

This paper describes in detail the electronic management application software system design and development process of marketing history archive. At present, the software system has basically completed, and marketing archives management applications are done practice test in Henan Province, the system performance meets need, function configuration is perfect and flexible, and get the user's consistent high praise.

\section{References}

[1] Wu Xiping, Duan Fanding, The management system design and development of the electric power marketing customer archive, Software Tribune, Vol.8, No.8, 2009.

[2] Zhang Xuezheng, The development and application of the electric power marketing customer archive management system, rural electrification, Vol.12, 2010.

[3] "GB/T 8567-2006", specifications of calculation and software documentation.

[4] "GB/T 5271.1-2000", information technology.

[5] "GB/T 11457-11457", software engineering.

[6] "GA/T 387-2002", computing and information system security level. 